Article - Agriculture, Agribusiness and Biotechnology

\title{
Characterization of a Chrysodeixis includens nucleopolyhedrovirus Isolate from Brazilian Cerrado and Assessment of its Co-Infection with Anticarsia gemmatalis multiple nucleopolyhedrovirus
}

Márcio Martinello Sanches ${ }^{1}$

https://orcid.org/0000-0002-4680-8879

William Sihler ${ }^{1}$

https://orcid.org/0000-0002-2696-1569

Cláudia Efigênia Pereira Silva ${ }^{1,2}$

https://orcid.org/0000-0001-8860-2492

Giovana Curcio Guimarães ${ }^{1,3}$

https://orcid.org/0000-0003-2302-0648

Norton Polo Benito 1

https://orcid.org/0000-0003-4423-9892

Daniel Ricardo Sosa-Gómez ${ }^{4}$

https://orcid.org/0000-0003-2633-1644

Marlinda Lobo de Souza ${ }^{1}$

https://orcid.org/0000-0001-9877-8627

'Embrapa Genetic Resources \& Biotechnology, Brasília-DF, Brazil; ${ }^{2}$ Universidade Paulista, UNIP, Brasília-DF, Brazil; ${ }^{3}$ Centro Universitário de Brasília, UNICEUB, Brasília-DF, Brazil; ${ }^{4}$ Embrapa Soybean, Londrina-PR, Brazil.

Received: 2018.11.27; Accepted: 2019.07.08.

*Correspondence: marcio.sanches@embrapa.br; Tel.: +55-61-34484695 (M.M.S.)

\section{HIGHLIGHTS}

- ChinNPV-Buritis is a potential isolate for the development of biopesticide.

- Its biological and molecular features are similar to other ChinNPV isolates.

- In vitro infection in SF21, Sf9, and Tn-5B1-4 cell lines presented few OBs.

- ChinNPV and AgMNPV co-infected Tn-5B1-4 cells in vitro. 
Abstract: Chrysodeixis includens has become the major Lepidopteran pest of soybean crops, especially in the Brazilian Cerrado (savanna) region. A native isolate of Chrysodeixis includens nucleopolyhedrovirus (ChinNPV) from this region, Buritis, MG, was assessed for its biological and molecular features. In addition, in vitro co-infection with Anticarsia gemmatalis multiple nucleopolyhedrovirus (AgMNPV), another virus of an important soybean pest, was tested. The ChinNPV-Buritis isolate presented an average $\mathrm{LC}_{50}$ of 7,750 occlusion bodies (OBs)/ml of diet in $C$. includens larvae. Analysis of restriction endonuclease profiles of viral DNA revealed similarities with previously described ChinNPV isolates IE, IF, and IG from Brazil, although the presence of submolar bands indicates genetic heterogeneity. Optical microscopy analysis in conjunction with quantitative PCR (qPCR) demonstrated in vitro infection of this isolate in IPLB-SF-21AE, Sf9, and BTI-Tn-5B1-4 cell lines, but the amount of ChinNPV tends to decrease through serial passages. The qPCR method developed in this study successfully detected both AgMNPV and ChinNPV from cell culture and from infected larvae. The cell line Tn-5B1-4 is indicated for future development of in vitro production and co-infection studies.

Keywords: AgMNPV; baculovirus; ChinNPV; soybean looper; velvetbean caterpillar.

\section{INTRODUCTION}

In the last few seasons, severe infestations of Lepidoptera larvae has occurred in the large Brazilian savanna region known as the Cerrado. The increase of larvae populations was due to the large areas for growing crops (soybean and cotton) and the intense use of fungicides to control Asian soybean rust, which reduces the entomopathogenic fungi inoculum (Metarhizium rileyi, Zoophthora radicans, Pandora gammae, Isaria tenuipes) ${ }^{1}$. In soybean, the most important defoliators are Chrysodeixis includens and Anticarsia gemmatalis. However, other species, such as Helicoverpa armigera and Spodoptera ( $S$. cosmioides, S. eridania, S. albula, and $S$. frugiperda) have also been reported, although with much lower prevalence and in restricted areas $^{2}$.

Control failures and pest resurgence have triggered the demand for biological control agents. The use of these agents is highly desirable due to their ability to be harmonized in Integrated Pest Management Programs (IPM). In this respect, baculovirus biopesticides are specific and natural control agents of their hosts. Viruses in the family Baculoviridae are host specific, infecting only one or a few closely related species of insects. The specificity is innately linked to the pathogenesis of this family of viruses. The occlusion derived virions (ODVs) that emerge from occlusion bodies (OBs) are the universal virion phenotype for all baculoviruses as they are responsible for the initial oral (per os) infection of host insect gut cells. In lepidopteran hosts, the initial, primary infection of midgut cells by ODVs is followed by secondary infection of tissues within the insect hemocoel that is affected by the budded virion (BV) phenotype. Dependence on the host-cell molecular machinery is reduced over the course of the infection as baculovirus gene expression and regulatory proteins take over. However, host and/or tissue-specific interactions continue to play a role as the infection progresses within the infected host, which will determine whether a patent infection will occur $^{3}$. 
The two most important soybean lepidopteran pests in Brazil can be infected by their specific baculoviruses such as Chrysodeixis includens nucleopolyhedrovirus (ChinNPV) and Anticarsia gemmatalis multiple nucleopolyhedrovirus (AgMNPV) ${ }^{4,5}$. Mixed infestations of soybean looper and velvetbean caterpillar in soybean fields have been controlled with conventional insecticides. AgMNPV has been widely used for microbial control of $A$. gemmatalis in Brazil, but its use has decreased since 2003-04 season, while $C$. includens populations became more common. Another factor that affected AgMNPV use has been the reluctance of companies to produce the virus in a competitive market with widespread adoption of Bt soybean, that had the same target pests ${ }^{1}$.

The limiting factors for the use of ChinNPV compared to AgMNPV include disruption of larvae integument, an undesirable characteristic for in vivo production, lower virulence than AgMNPV, and restraints on soybean looper mass rearing due to endogamy and colony depletion ${ }^{1}$. A ChinNPV was isolated from $C$. includens in the region of Buritis - Minas Gerais State, located in the Brazilian Cerrado, in 2014. Natural epizootics were reported in $C$. includens larvae infesting soybean crops in that area, promoting mortality in about $30 \%$ of the larvae, which reveals the potential of this virus to be used as a biopesticide ${ }^{5}$.

In vitro production could potentially overcome the difficulties of large-scale production of baculovirus biopesticides ${ }^{6}$. Therefore, insect cell cultures are interesting systems that support viral replication ${ }^{7,8,9}$. However, due to several technical limitations and prohibitive costs of production, baculovirus in vitro production is still unpractical on the commercial scale ${ }^{9}$.

Co-infection of two different viral genotypes can result in co-occlusion phenotype ${ }^{10,11,12}$. In vitro co-infection studies based on the recombinant Autographa californica multiple nucleopolyhedrovirus (AcMNPV) lacking the polyhedrin gene and the wild-type AcMNPV resulted in co-occluded virus ${ }^{10,13}$. In addition, Arrizubieta et al. ${ }^{12}$ studied in vivo co-infection with different genotypes of Helicoverpa armigera single nucleopolyhedrovirus (HearSNPV) in $H$. armigera larvae. After five in vivo passages of the co-occluded virus, the amount of one genotype increased and the resulting occlusion body $(\mathrm{OB})$ became more virulent and pathogenic. This present work aimed to evaluate biological and molecular features of ChinNPV, obtained from Buritis, and its in vitro replication in insect cell lines. In addition, in vitro co-infection of AgMNPV and ChinNPV was tested, as well as the methods to assess the proportions of each virus produced in cells and larvae.

\section{MATERIAL AND METHODS}

\section{Insect colony and virus stock}

Colonies of $A$. gemmatalis and $C$. includens were maintained at $26 \pm 2{ }^{\circ} \mathrm{C}, 70 \%$ relative humidity $(\mathrm{RH})$, and $13 \mathrm{~h}$ photophase. Larvae were reared as described by Hoffmann-Campo et al. ${ }^{14}$ on an artificial diet ${ }^{15}$. All bioassays were conducted on third instar larvae under the same rearing conditions, $26 \pm 1.5^{\circ} \mathrm{C}, 14 \mathrm{~h}$ photophase, and $75 \% \mathrm{RH}$. A. gemmatalis larvae were infected with AgMNPV-2 $\mathrm{d}^{16}$ and $C$. includens infected with ChinNPV-Buritis isolate ${ }^{5}$. The virus isolates were incorporated into the artificial diet (concentration $10^{7} \mathrm{OBs} / \mathrm{ml}$ ) to produce a virus stock for further experiments. 


\section{Occlusion body purification and DNA extraction}

Dead larvae were kept in the freezer and later used for occlusion body (OB) purification. Insect cadavers were homogenized with buffer (1\% ascorbic acid; $2 \%$ SDS; $0.01 \mathrm{M}$ Tris $\mathrm{pH}$ 7.8; 0.001M EDTA pH 8.0), filtered through three layers of cheesecloth, and centrifuged at $7,000 \times \mathrm{g}$ for $10 \mathrm{~min}$. The pellet was suspended in TE buffer $(0.01 \mathrm{M}$ Tris- $\mathrm{HCl} \mathrm{pH} 8.0$ and $0.001 \mathrm{M}$ EDTA $\mathrm{pH} 8.0$ ) and again centrifuged at 7,000 $\times \mathrm{g}$ for $10 \mathrm{~min}$. The dilution and centrifugation steps were repeated four times. The pellet was loaded onto a continuous 1.17 to $1.30 \mathrm{~g} / \mathrm{ml}$ sucrose gradient, and centrifuged at $104,000 \times \mathrm{g}$ for $40 \mathrm{~min}$ at $4{ }^{\circ} \mathrm{C}$. The $\mathrm{OB}$ band was collected, diluted 4-fold in TE buffer, and centrifuged at 7,000 $\times \mathrm{g}$ for $15 \mathrm{~min}$ at 4 ${ }^{\circ} \mathrm{C}^{17}$. The OB concentration in the suspension was determined using a Neubauer chamber under a microscope $(400 \times)$. Purified occlusion bodies $\left(10^{9} \mathrm{OBs} / \mathrm{ml}\right)$ were dissolved in an alkaline solution ( $0.1 \mathrm{M}$ sodium carbonate) and used to extract DNA according to O'Reilly et al. ${ }^{18}$.

\section{Viral genomic DNA restriction analyses}

The viral DNA $(1-2 \mu \mathrm{g})$ of ChinNPV-Buritis was individually cleaved with the restriction enzymes Hindll, EcoRI, and BamHI (Invitrogen) according to the manufacturer's instructions. The generated DNA fragments were subjected to electrophoresis in $0.8 \%$ agarose gel $^{19}$. The restriction endonuclease profile of Buritis isolate was compared to the DNA profiles of three ChinNPV isolates analyzed by Alexandre et al. ${ }^{20}$. The most similar profiles were submitted to in silico restriction analysis based on sequences published by Craveiro et al. ${ }^{21}$ (GenBank accession numbers: NC026268, KU669293, KU669294) using Geneious 7.1 software. Each sequence was digested in silico with Hindll, EcoRI, and $\mathrm{BamHI}$ restriction enzymes and separated on a virtual agarose gel for comparison.

\section{Biological activity of ChinNPV-Buritis isolate}

Two bioassays were performed according to Morales and Moscardi22. Viral OBs were incorporated into the artificial diet and offered to third instar $C$. includens larvae. Six concentrations were used: $80,220,605,1670,4580$, and $12580 \mathrm{OBs} / \mathrm{ml}$ of diet (Greene et al. ${ }^{15}$. For each treatment, 60-62 larvae were tested. For negative control, the virus suspension was not incorporated to the artificial diet. Larvae were maintained in a B.O.D incubator at a temperature of $26 \pm 1.5^{\circ} \mathrm{C}$ and $14 \mathrm{~h}$ photophase. For mortality analysis, daily observations were made for 15 days. At the end of the trials, the mortality data were corrected using the Abbott's formula ${ }^{23}$ and analyzed by probit analysis to determine the lethal concentration $\left(\mathrm{LC}_{50}\right)$ values with respective $95 \%$ fiducial limits $(C L)^{24}$. Analysis was conducted using the Polo Plus Version 2.0 software (LeOra Software).

\section{Cell culture}

Trichoplusia ni BTI-Tn-5B1-425, also known as High Five cells, Spodoptera frugiperda IPLB-SF-21AE ${ }^{26}$ and $\mathrm{Sfg}^{27}$ were used for in vitro assays. The cell lines were maintained at $27{ }^{\circ} \mathrm{C}$ in TNMFH [Grace's insect medium (Gibco-BRL) supplemented with lactalbumin hydrolysate and yeastolate] containing $10 \%$ heat-inactivated bovine fetal serum. 


\section{In vitro assays and DNA extraction}

The cells were seeded at a density of $1 \times 10^{6}$ per $60 \mathrm{~mm}^{2}$ well. The viruses were obtained through hemolymph from infected larvae at 4 d.p.i. (days post infection) and allowed to adsorb into cells for 1 hour (passage zero - P0). Infected cells were kept in TNMFH complete medium at $27^{\circ} \mathrm{C}$. Morphological analysis was initially monitored by light microscopy for five days. Then, the supernatants $(100 \mu l)$ were collected for new infections (P1) using the same procedure. At 5 d.p.i., the supernatants were collected for the second passage (P2). The morphology from P1 and P2 passages were also monitored by light microscopy. Aliquots of supernatant of each passage $(100 \mu \mathrm{l})$ were collected for DNA purification and real-time PCR (qPCR) tests. The experiment was performed twice. The OBs obtained in the passages were collected, and the concentration was determined using a Neubauer hemocytometer under phase contrast microscopy at $400 \times$. The OBs suspensions $(100 \mu \mathrm{l})$ were dissolved in an alkaline solution and used to extract DNA with DNeasy Blood \& Tissue (Qiagen) following the manufacturer's instructions and then for qPCR tests in duplicates. For co-infection assays, the same amount of AgMNPV and ChinNPV infected hemolymph (100 $\mu$ l each) per well was used and allowed to adsorb into cells in the P0 infection. During P1 and P2 passages, the same procedure of the single infection was applied.

\section{Real-time PCR (qPCR) standardization}

Specific primers were designed for distinct genes of AgMNPV ${ }^{28}$ and ChinNPV ${ }^{21}$ based on Genbank sequences database. The primer pair gp64FW (5'TAACGGGGGTGTCATCAACG 3') / gp64RV (5'GTTTGCGCCTAATACAGCGG 3') was designed for gp64 of AgMNPV. The primer pair PholyFW (5'CACCAAGAAAGGAGGCGTGA3') / PholyR (5'ACAGTCGTCGAGCATCACAA 3') was designed for photolyase of ChinNPV. The qPCR reaction was made with Rotor Gene SYBR Green Master Mix (Qiagen) using $0.2 \mu \mathrm{M}$ of each primer and $1 \mu \mathrm{l}$ of DNA (1 $\mathrm{ng} / \mu \mathrm{l})$, following the manufacturer's instructions. The assays were done in a Rotor gene 5plex HRM platform (Qiagen). Samples were subjected to the following conditions: $95^{\circ} \mathrm{C}$ for $5 \mathrm{~min} ; 40$ cycles of $95^{\circ} \mathrm{C}$ for $5 \mathrm{sec}$ and $60^{\circ} \mathrm{C}$ for $10 \mathrm{sec}$. A melting curve analysis was performed to assure that a homogenous amplification product had been produced. The GPCR products were visualized by electrophoresis on $1 \%$ agarose gel in TAE. To determine the standard curve of the assays, a series of 10 -fold dilutions (ranging from 1 to $10^{-10}$ ) of viral DNA was tested in triplicate. Dilution 1 corresponds to $10 \mathrm{ng} / \mu \mathrm{l}$ for both viruses. The DNA concentration was checked using a Nanodrop 2000 microvolume spectrophotometer (Thermo Scientific) and compared to low DNA mass ladder (Invitrogen) in $0.8 \%$ agarose gel electrophoresis.

The presence of false-positives results was tested with DNA obtained from the larvae and cell culture controls without viruses. In addition, the possible detection of non-target virus species was verified. To validate the detection parameters previously determined in the standard curve, the following dilutions of OBs were performed: (mix 1)- $1 \times 10^{6} \mathrm{OBs} / \mu \mathrm{l}$ ChinNPV and $5 \mathrm{OBs} / \mu \mathrm{l} \mathrm{AgMNPV;} \mathrm{(mix} \mathrm{2)-} 5 \times 10^{5} \mathrm{OBs} / \mu \mathrm{l}$ AgMNPV and $10 \mathrm{OBs} / \mu \mathrm{l} \mathrm{ChinNPV;}$ (mix 3)- $10^{3} \mathrm{OBs} / \mu \mathrm{l}$ of each virus. The larvae, cell culture and OBs mixtures were submitted to DNA extraction with DNeasy Blood \& Tissue (Qiagen) following the manufacturer's instructions and then to qPCR tests in duplicate. 


\section{Biological activity of OBs obtained from in vitro co-infection}

OBs obtained from in vitro AgMNPV and ChinNPV co-infection were collected to infect A. gemmatalis and $C$. includens larvae. Three bioassays were conducted using different OBs concentrations (Table 1).

Table 1. Bioassays performed to analyze the biological activity of OBs obtained from in vitro AgMNPV and ChinNPV co-infection.

\begin{tabular}{lll}
\hline Bioassay - Inoculum & OB concentration & Number of larvae \\
\hline B1 - in vitro P0 passage & $10^{2} \mathrm{OBs} / \mathrm{ml}$ & $100 \mathrm{~A}$. gemmatalis \\
& & $100 \mathrm{C}$. includens \\
B2 - OBs from infected $A$. & - & $24 \mathrm{C}$. includens \\
gemmatalis (B1 assay) & & \\
B3 - in vitro P0 passage & $10^{7} \mathrm{OBs} / \mathrm{ml}$ & $40 \mathrm{~A}$. gemmatalis \\
& & $40 \mathrm{C}$. includens \\
\hline
\end{tabular}

In the first bioassay (B1), an $\mathrm{OB}$ suspension $\left(10^{2} \mathrm{OBs} / \mathrm{ml}\right)$ from $\mathrm{P} 0$ passage of coinfected cells was prepared. Soybean leaf disks $(1 \mathrm{~cm})$ were inoculated with $10 \mu \mathrm{l}$ of the OB suspension (estimated to contain one $\mathrm{OB}$ ). Each leaf disk was offered to a single larva. The bioassay was conducted with $100 \mathrm{C}$. includens larvae and $100 \mathrm{~A}$. gemmatalis larvae. On the second day, a leaf disk was replaced by artificial diet until 7 d.p.i.

For the second bioassay (B2), the OBs obtained from dead A. gemmatalis of B1 were used as inoculum. A suspension was prepared with macerated larvae in distilled water (1:10 proportion). Soybean leaf disks $(1 \mathrm{~cm})$ were inoculated with $10 \mu \mathrm{l}$ of the suspension/leaf disk. Each leaf disk was offered to a single larva. The bioassay was conducted with $24 \mathrm{C}$. includens larvae in the same conditions as the first bioassay.

In the third bioassay (B3), an OB suspension $\left(10^{7} \mathrm{OBs} / \mathrm{ml}\right)$ from $\mathrm{PO}$ passage of coinfected cells was prepared. Slices of artificial diet $(1 \mathrm{~cm})$ were inoculated with $5 \mu \mathrm{l}$ of the OB suspension. Each slice was offered to a single larva. The bioassay was conducted with $40 \mathrm{C}$. includens larvae and $40 \mathrm{~A}$. gemmatalis larvae until 7 d.p.i. For all bioassays, the dead or symptomatic larvae (polyhedrosis disease) were individually collected for DNA extraction and $\mathrm{qPCR}$ as previously described. In addition, a control treatment without virus was conducted in the same conditions, using same number of larvae for each species.

\section{RESULTS}

\section{DNA restriction profile and biological activity of ChinNPV-Buritis}

Characterization of the ChinNPV isolated from Buritis-MG (Brazil) was done by comparing its restriction endonuclease DNA profile to other ChinNPV isolates described by Alexandre et al. ${ }^{20}$. A similar profile was observed with the presence of more than 20 fragments in the digestions with BamHI, EcoRI, Hindll, and presence of submolar bands, indicating this isolate might be a mixture of different genotypes (Fig. 1). Since the restriction endonuclease profile resembles that observed in IE, IF, and IG isolates (collected at 
Iguaraçu-PR, Dourados-MS, and Sertanópolis-PR, Brazil, respectively), they were chosen for in silico DNA endonuclease digestion for more detailed comparison. The analysis revealed a distinct EcoRI profile of ChinNPV-Buritis, presenting the fragment of $15 \mathrm{~kb}$ observed for the IF and IG and the fragments of $11 \mathrm{~kb}$ and $3.6 \mathrm{~kb}$ observed for IE. The in silico EcoRI digestion analysis for isolates IF and IG differed from that performed with viral DNA by Alexandre et al. ${ }^{20}$, which have the fragments of $11 \mathrm{~kb}$ and $3.6 \mathrm{~kb}$. Virulence assays to its host ( $C$. includens) found that ChinNPV-Buritis isolate presented average $\mathrm{LC}_{50}$ of 7,750 $\mathrm{OB} / \mathrm{ml}$ (Table 2), which is an intermediate value between the $\mathrm{LC}_{50}$ of the isolates, IE/F and IG. The IE and IF isolates presented the lowest LC $_{50}$ among the six Brazilian isolates compared by Alexandre et al. ${ }^{20}$. However, the IG had the highest $L_{50}$ among these isolates.

Table 2. Lethal concentration $\left(\mathrm{LC}_{50}\right)$ of ChinNPV-Buritis isolate $\left(\mathrm{OB} \times \mathrm{mL}^{-1}\right)$ incorporated into the artificial diet and offered to third instar $C$. includens larvae

\begin{tabular}{llllllll}
\hline Treatment & Days p.i. & $\mathbf{N}^{1}$ & $\mathbf{L C}_{50}$ & $\mathbf{C l} \mathbf{( 9 5 \% )}$ & Slope $\pm\left(\mathbf{S E}^{2}\right)$ & $\mathbf{d f}$ & $\mathbf{X}^{\mathbf{2}}$ \\
\hline First & 15 & 432 & 8792 & $5602-16752$ & $1.031 \pm 0.179$ & 4 & 3.712 \\
Second & 15 & 417 & 6709 & $3834-14110$ & $1.736 \pm 0.285$ & 4 & 4.3673 \\
\hline
\end{tabular}

$\mathrm{N}^{1}=$ number of insects tested

$\mathrm{SE}^{2}=$ Standard error

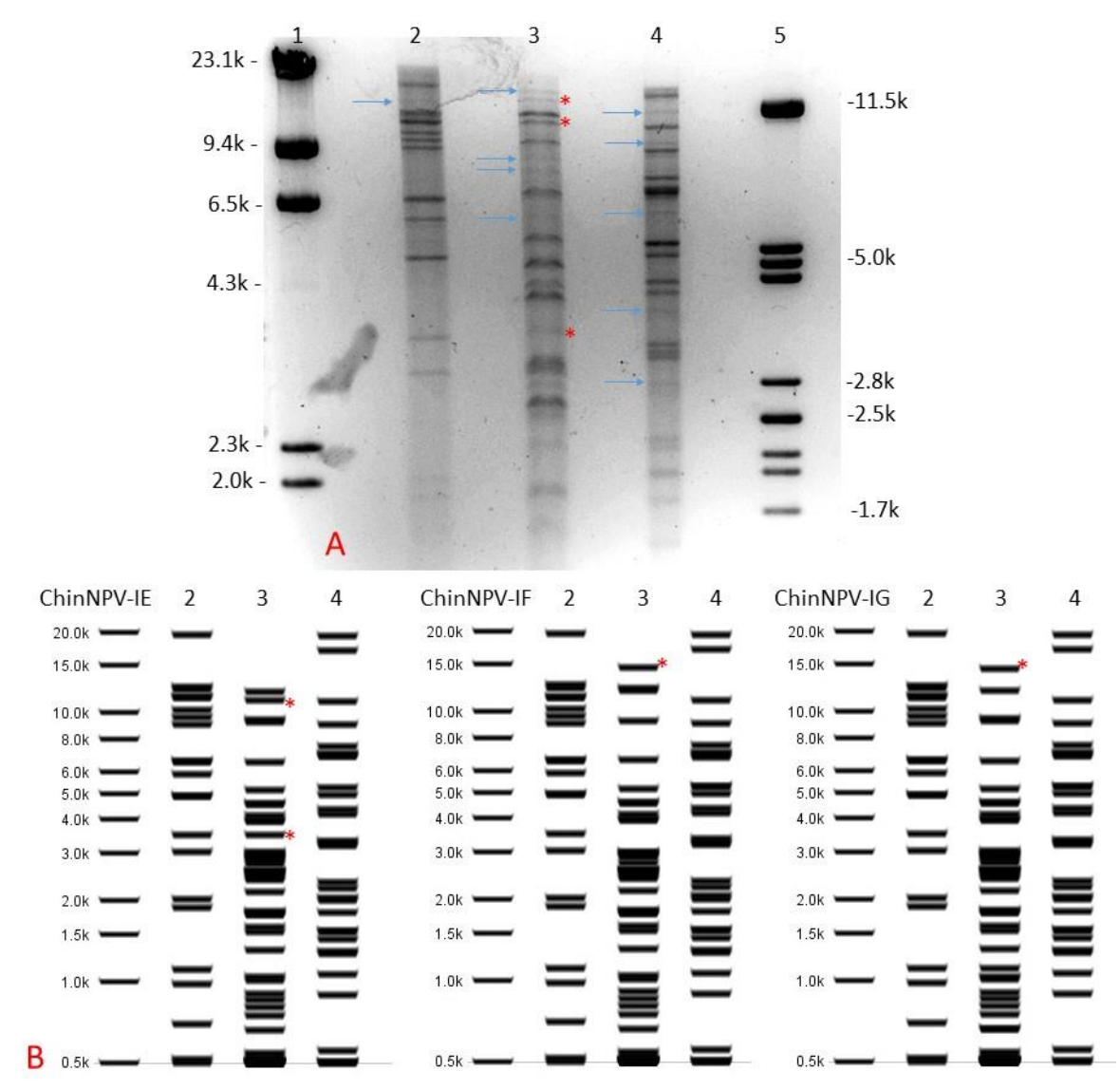

Figure 1. Restriction endonuclease profile of ChinNPV-Buritis DNA (A) and in silico restriction endonuclease profile of ChinNPV-IE, ChinNPV-IF, and ChinNPV-IG based on DNA sequences available on GenBank (B). ChinNPV DNA was digested with BamHI (2), EcoRI (3), and HindllI (4). Molecular marker DNA $\wedge$ HindIII (1) and DNA $\wedge$ Pstl (5). Restriction fragments were separated by electrophoresis in $0.8 \%$ agarose gel. Arrowed fragments are submolar bands present in ChinNPVBuritis, and asterisks indicate bands unique to isolates IE, IF, and IG present in ChinNPV-Buritis. 


\section{Analysis of specificity, sensibility, and reproducibility of Real-time qPCR}

The primers designed for the qPCR efficiently detected the viruses. The healthy larvae and cell culture controls did not show amplification. There were no false-positive results for non-target viruses. The melting curve analysis showed a single peak for both primer pairs, indicating high specificity. The amplicons visualized after electrophoresis analysis presented the expected size, while non-specific products were not amplified. For the primer pair gp64FW/RV, the standard curve exhibited the equation of $y=-3.596 x+15.250$ and the coefficient of correlation $\left(R^{2}\right)$ of 0.997 . It displayed an amplification efficiency of $90 \%$. For the primer pair PholyFW/PholyRV, the standard curve showed the equation of $y=-3.507 x$ +13.852 and the coefficient of correlation $\left(R^{2}\right)$ of 0.998 . It displayed an amplification efficiency of $93 \%$.

The detection limit of both reactions was $10^{-5} \mathrm{ng}$ DNA, which corresponded to two OBs of AgMNPV and four OBs of ChinNPV in this assay. The validation of detection parameters presented minimal variation in the technical duplicate and in the assays repeated in time (Table 3), demonstrating the reproducibility of the technique. This variation should be considered normal due to the different number of virions in each $\mathrm{OB}$, as well as the intrinsic characteristic of nucleic acid extraction methods ${ }^{29,30}$.

Table 3. Real-time qPCR quantification of photolyase and gp64 genes in DNA extracted from mixtures of AgMNPV and ChinNPV occlusion bodies

\begin{tabular}{|c|c|c|}
\hline \multirow[t]{2}{*}{ Mixtures } & \multicolumn{2}{|c|}{ 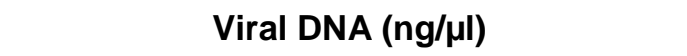 } \\
\hline & ChinNPV - photolyase & AgMNPV- gp64 \\
\hline \multicolumn{3}{|l|}{ Experiment 1} \\
\hline $1 \times 10^{6} \mathrm{OBs} / \mu \mathrm{l}$ ChinNPV $+5 \mathrm{OBs} / \mu \mathrm{l}$ AgMNPV & 9.12 & $1.67 \times 10^{-3}$ \\
\hline $5 \times 10^{5} \mathrm{OBs} / \mu \mathrm{l}$ AgMNPV $+10 \mathrm{OBs} / \mu \mathrm{l}$ ChinNPV & $1.79 \times 10^{-4}$ & 16.0 \\
\hline $10^{3} \mathrm{OBs} / \mu \mathrm{l}$ of $\mathrm{AgMPNV}+10^{3} \mathrm{OBs} / \mu \mathrm{l}$ ChinNPV & $2.79 \times 10^{-2}$ & $6.22 \times 10^{-2}$ \\
\hline \multicolumn{3}{|l|}{ Experiment 2} \\
\hline $1 \times 10^{6} \mathrm{OBs} / \mu \mathrm{l}$ ChinNPV $+5 \mathrm{OBs} / \mu \mathrm{l}$ AgMNPV & 7.05 & $2.08 \times 10^{-3}$ \\
\hline $5 \times 10^{5} \mathrm{OBs} / \mu \mathrm{l}$ AgMNPV+ $10 \mathrm{OBs} / \mu \mathrm{l}$ ChinNPV & $6.15 \times 10^{-4}$ & 12.6 \\
\hline $10^{3} \mathrm{OBs} / \mu \mathrm{l}$ of $\mathrm{AgMPNV}+10^{3} \mathrm{OBs} / \mu \mathrm{l}$ ChinNPV & $3.90 \times 10^{-2}$ & $5.55 \times 10^{-2}$ \\
\hline
\end{tabular}

\section{In vitro assays}

Single infection of ChinNPV in SF21, Sf9, and Tn-5B1-4 cell lines resulted in low OBs production. Cell culture visualization by optical microscopy (Fig. 2), in conjunction with the qPCR assays of cell culture supernatants (Table 4), indicates that infection with ChinNPV is restricted to individual cells. The best OB production occurred in Tn-5B1-4 cell lines. In SF21 and Sf9 cell lines, OBs production was observed only in a few cells.

The results confirmed that ChinNPV viral DNA concentration decreases over passage even in the presence of AgMNPV. However, the amount of AgMNPV tends to increase in the first passage and to stabilize in the second passage (Table 4). Both viruses were also detected in the qPCR test from OBs collected from in vitro co-infections, although the amount of ChinNPV was low compared to AgMNPV (Table 5). 

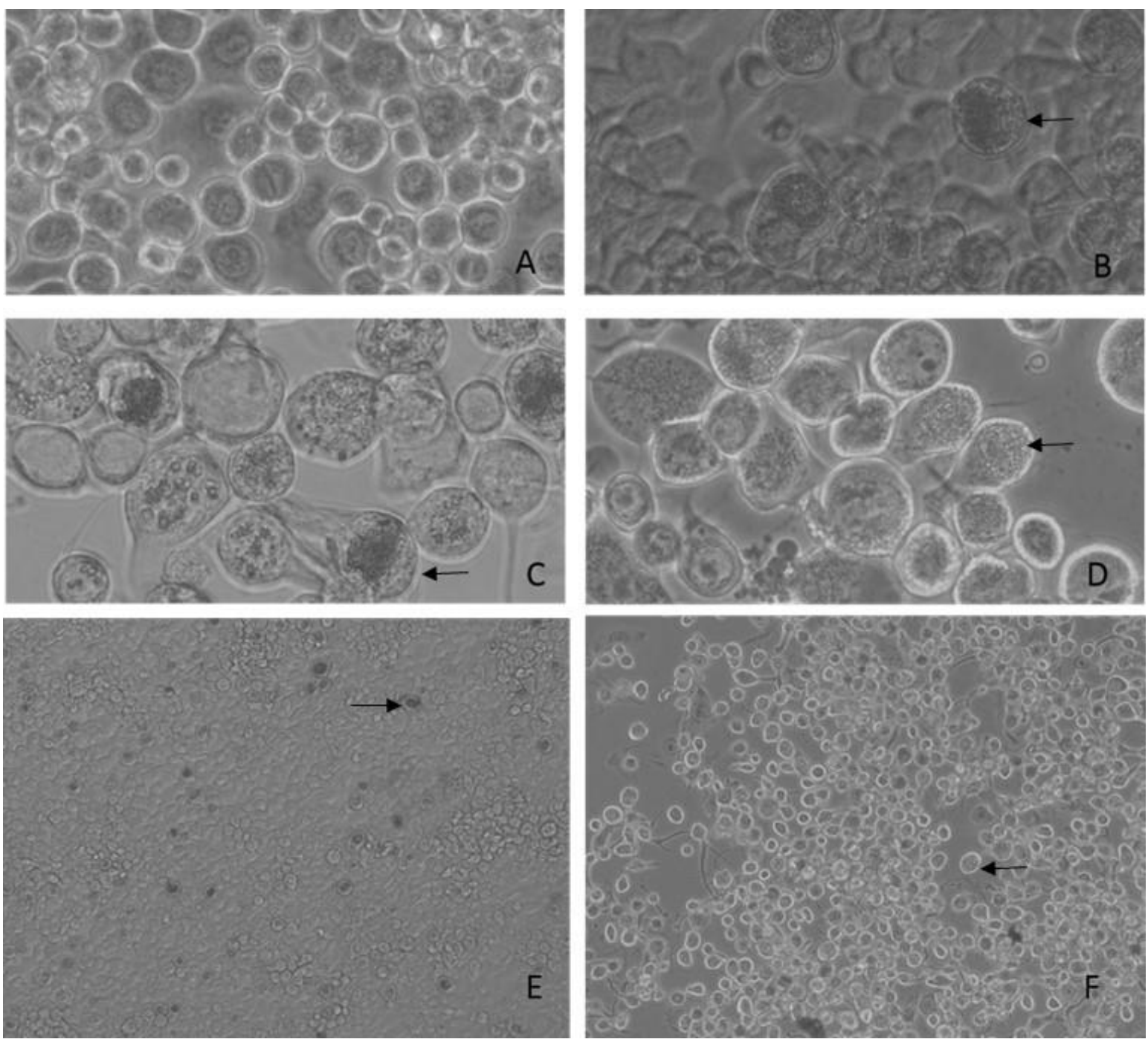

Figure 2. Phase-contrast micrographs of T. ni BTI-Tn 5B1-4 cells - P0 passage at $96 \mathrm{~h}$ p.i. Mockinfected cells (A). Cells infected with ChinNPV-Buritis (B). Cells co-infected with ChinNPV-Buritis and AgMNPV-2d (C). Cells infected with AgMNPV-2d (D) (20x objective). Cells infected with ChinNPV-Buritis $(E)$ and cells co-infected with ChinNPV-Buritis and AgMNPV-2d $(F)$ at 10xobjective. The arrows show the OBs and cytopathic effects in the cells. 
Table 4. Real-time qPCR quantification of photolyase and gp64 genes in DNA extracted from cell culture supernatant infected with ChinNPV and co-infected with AgMNPV and ChinNPV.

\begin{tabular}{|c|c|c|c|c|}
\hline \multirow[t]{2}{*}{ Passage } & \multirow[t]{2}{*}{ Cell line } & \multirow{2}{*}{ 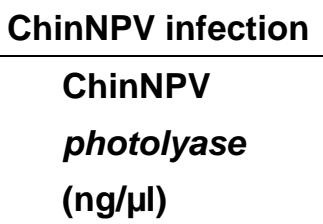 } & \multicolumn{2}{|c|}{ ChinNPV+AgMNPV co-infection } \\
\hline & & & $\begin{array}{l}\text { ChinNPV } \\
\text { photolyase (ng/ } \mu \mathrm{l})\end{array}$ & $\begin{array}{l}\text { AgMNPV } \\
g p 64(\mathrm{ng} / \mu \mathrm{l})\end{array}$ \\
\hline \multicolumn{5}{|c|}{ Experiment 1} \\
\hline \multirow[t]{3}{*}{ Po } & Sf21 & $N T^{*}$ & $1.2 \times 10^{-4}$ & 0.11 \\
\hline & Sf9 & NT & $2.8 \times 10^{-4}$ & $6.2 \times 10^{-2}$ \\
\hline & Tn5B1-4 & $2.4 \times 10^{-3}$ & $1 \times 10^{-4}$ & $9.6 \times 10^{-3}$ \\
\hline \multirow[t]{3}{*}{$\mathrm{P} 1$} & Sf21 & $4.2 \times 10^{-4}$ & $2.5 \times 10^{-5}$ & 1.1 \\
\hline & Sf9 & $2.8 \times 10^{-4}$ & $1.7 \times 10^{-5}$ & 0.3 \\
\hline & Tn5B1-4 & $2.8 \times 10^{-4}$ & $1.3 \times 10^{-5}$ & 0.32 \\
\hline \multirow[t]{3}{*}{ P2 } & Sf21 & $1.2 \times 10^{-5}$ & ND & 0.23 \\
\hline & Sf9 & $4 \times 10^{-6}$ & ND & 0.17 \\
\hline & Tn5B1-4 & $6.3 \times 10^{-6}$ & ND & $7.5 \times 10^{-2}$ \\
\hline \multicolumn{5}{|c|}{ Experiment 2} \\
\hline \multirow[t]{3}{*}{ P0 } & Sf21 & NT & $7.7 \times 10^{-6}$ & $1.3 \times 10^{-2}$ \\
\hline & Sf9 & NT & $8.2 \times 10^{-6}$ & $5.4 \times 10^{-3}$ \\
\hline & Tn5B1-4 & $9.9 \times 10^{-5}$ & $5.2 \times 10^{-6}$ & $2.3 \times 10^{-2}$ \\
\hline \multirow[t]{3}{*}{$\mathrm{P} 1$} & Sf21 & $1.3 \times 10^{-5}$ & ND & $7.5 \times 10^{-2}$ \\
\hline & Sf9 & $1 \times 10^{-5}$ & ND & $2.7 \times 10^{-2}$ \\
\hline & Tn5B1-4 & $3 \times 10^{-6}$ & ND & $4.7 \times 10^{-2}$ \\
\hline \multirow[t]{3}{*}{ P2 } & Sf21 & $N^{*}$ & ND & $3.7 \times 10^{-2}$ \\
\hline & Sf9 & ND & ND & $2.3 \times 10^{-2}$ \\
\hline & Tn5B1-4 & ND & ND & $4 \times 10^{-3}$ \\
\hline
\end{tabular}

${ }^{*} \mathrm{NT}$ : non tested; ND: non detected

Table 5. Real-time qPCR quantification of photolyase and gp64 genes in DNA extracted from occlusion bodies obtained in cell culture co-infected with AgMNPV and ChinNPV

\begin{tabular}{|c|c|c|}
\hline \multirow[t]{2}{*}{ Sample } & \multicolumn{2}{|c|}{ 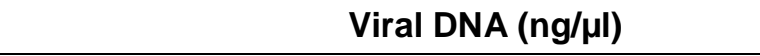 } \\
\hline & ChinNPV - photolyase & AgMNPV- gp64 \\
\hline \multicolumn{3}{|c|}{ Experiment 1} \\
\hline PO & $3.4 \times 10^{-4}$ & 3.46 \\
\hline P1 & $9.8 \times 10^{-5}$ & 3.89 \\
\hline P2 & $7.17 \times 10^{-6}$ & 1.97 \\
\hline \multicolumn{3}{|c|}{ Experiment 2} \\
\hline PO & $8.31 \times 10^{-4}$ & 3.25 \\
\hline P1 & $3.04 \times 10^{-4}$ & 4.06 \\
\hline P2 & $3.17 \times 10^{-5}$ & 1.79 \\
\hline
\end{tabular}




\section{Biological activity of OBs obtained from in vitro co-infection}

Low mortality was observed in $A$. gemmatalis (6\%) and $C$. includens (4\%) larvae in the bioassay B1. Ten $A$. gemmatalis and ten $C$. includens larvae displayed symptoms of polyhedrosis disease, but they remained alive until 7 d.p.i. The qPCR analysis from larvae of B1 (Tables 6 and 7) detected only ChinNPV in the dead larvae (one A. gemmatalis and three $C$. includens), however, at low concentrations. AgMNPV was not detected in the dead larvae, and both viruses were not detected in diseased larvae. The reasons for these negative results could be mortality caused by other agents or that the quantity of viruses was below the limit of detection of the method used. It is relevant to consider that these samples had low total DNA concentration ( 1 to $5 \mathrm{ng} / \mu \mathrm{l})$. In the bioassay $\mathrm{B} 2$, no dead or diseased $C$. includens larvae was observed until 7 d.p.i. Therefore, a qPCR of alive larvae was performed. Interestingly, both viruses occurred in the symptomless larvae, but at low concentrations, indicating survival with non-lethal dose (data not shown).

Table 6. Real-time qPCR quantification of photolyase and gp64 genes in DNA extracted from dead A. gemmatalis larvae to confirm the co-infection *

\begin{tabular}{lll}
\hline Sample number & \multicolumn{2}{c}{ Viral DNA (ng/ $\mathbf{\mu l})$} \\
\cline { 2 - 3 } & ChinNPV - photolyase & AgMNPV- $g$ p64 \\
\hline B1-1 & $1 \times 10^{-5}$ & ND \\
B1-2 & ND & ND \\
B1-3 & ND & ND \\
B1-4 & ND & ND \\
B1-5 & ND & ND \\
B1-6 & ND & ND \\
B3-1 & $7.31 \times 10^{-6}$ & 12.77 \\
B3-2 & $4.91 \times 10^{-6}$ & 10.25 \\
B3-3 & $5.19 \times 10^{-6}$ & 12.93 \\
B3-4 & $8.21 \times 10^{-6}$ & 12.2 \\
B3-5 & $1.36 \times 10^{-5}$ & 4.15 \\
B3-6 & $2.84 \times 10^{-5}$ & 9.77 \\
B3-7 & $1.14 \times 10^{-4}$ & 34.82 \\
B3-8 & $6.1 \times 10^{-4}$ & 28.81 \\
B3-9 & $1.5 \times 10^{-3}$ & 17.11 \\
B3-10 & $5.16 \times 10^{-4}$ & 33.3 \\
B3-11 & $3.12 \times 10^{-4}$ & 15.2 \\
B3-12 & $1.07 \times 10^{-4}$ & 31.8 \\
B3-13 & $1.1 \times 10^{-4}$ & 28.37 \\
B3-14 & $4.41 \times 10^{-4}$ & 26.62 \\
B3-15 & $2.14 \times 10^{-4}$ & 22.33 \\
\hline
\end{tabular}

${ }^{*}$ Bioassay B1 performed with 100 larvae - Concentration of $10^{2} \mathrm{OBs} / \mathrm{ml}$

Bioassay B3 performed with 40 larvae - Concentration of $10^{7} \mathrm{OBs} / \mathrm{ml}$. Only larvae with mixed infection is shown.

ND - Non detected 
In the bioassay B3, high mortality of $A$. gemmatalis larvae (91.5\%) and low mortality of C. includens larvae (5.5\%) was observed at 7 d.p.i. However, $13(36 \%)$ C. includens larvae showed polyhedrosis disease symptoms and were collected for DNA extraction and qPCR. The qPCR results indicated that all dead $A$. gemmatalis larvae had high quantities of AgMNPV. On the other hand, only 15 of these dead $A$. gemmatalis larvae presented ChinNPV (Table 6), but in low quantities. This result reflects the differences observed in the quantities of each virus species in the inoculum (OBs collected from the P0 passage) (Table 5). The two dead $C$. includens larvae presented high amounts of ChinNPV and low quantity of AgMNPV (Table 7). However, note that all the live symptomatic $C$. includens larvae presented both viruses in similar quantity, except for one that displayed a high quantity of ChinNPV. In some of these larvae, the amount of AgMNPV was higher than the quantity of ChinNPV.

Table 7. Real-time qPCR quantification of photolyase and gp64 genes in DNA extracted from dead or symptomatic $C$. includens larvae to confirm the co-infection *

\begin{tabular}{|c|c|c|}
\hline \multirow[t]{2}{*}{ Sample number } & \multicolumn{2}{|c|}{ Viral DNA (ng/ $\mu \mathrm{l})$} \\
\hline & ChinNPV - photolyase & AgMNPV- gp64 \\
\hline \multicolumn{3}{|l|}{ (dead larvae) } \\
\hline $\mathrm{B} 1-1$ & $9.1 \times 10^{-6}$ & ND \\
\hline B1-2 & $3.7 \times 10^{-5}$ & ND \\
\hline B1-3 & $2.7 \times 10^{-5}$ & ND \\
\hline B1-4 & ND & ND \\
\hline B3-14 & 23 & $2.72 \times 10^{-3}$ \\
\hline B3-15 & 89.7 & $3.04 \times 10^{-3}$ \\
\hline \multicolumn{3}{|c|}{ (symptomatic larvae) } \\
\hline B3-1 & $3.35 \times 10^{-3}$ & $2.47 \times 10^{-4}$ \\
\hline B3-2 & $4.3 \times 10^{-4}$ & $3 \times 10^{-4}$ \\
\hline B3-3 & $1 \times 10^{-3}$ & $3.8 \times 10^{-4}$ \\
\hline B3-4 & 5.47 & $1 \times 10^{-4}$ \\
\hline B3-5 & $6.35 \times 10^{-4}$ & $1.41 \times 10^{-4}$ \\
\hline B3-6 & $5.6 \times 10^{-4}$ & $7.73 \times 10^{-4}$ \\
\hline B3-7 & $1.5 \times 10^{-4}$ & $1.65 \times 10^{-4}$ \\
\hline B3-8 & $6.14 \times 10^{-4}$ & $6.7 \times 10^{-4}$ \\
\hline B3-9 & $1.5 \times 10^{-4}$ & $1.06 \times 10^{-3}$ \\
\hline B3-10 & $1.31 \times 10^{-5}$ & $1.53 \times 10^{-4}$ \\
\hline B3-11 & $5.46 \times 10^{-4}$ & $2.35 \times 10^{-4}$ \\
\hline B3-12 & $2.06 \times 10^{-4}$ & $6.44 \times 10^{-5}$ \\
\hline B3-13 & $9.75 \times 10^{-4}$ & $2 \times 10^{-4}$ \\
\hline
\end{tabular}

* Bioassay B1 performed with 100 larvae - Concentration of $10^{2} \mathrm{OBs} / \mathrm{ml}$ Bioassay B3 performed with 40 larvae - Concentration of $10^{7} \mathrm{OBs} / \mathrm{ml}$ ND - Non detected 


\section{DISCUSSION}

The ChinNPV isolate collected in the Brazilian Cerrado region (Buritis, MG) was first analyzed in terms of its restriction DNA profile and virulence. For biocontrol, a more important aspect than the genetic variation of the virus isolates is their phenotypic implications on pest management. The isolate ChinNPV-Buritis presented genetic heterogeneity revealed by the presence of submolar bands in the restriction endonuclease profile and a distinct EcoRI digestion profile, sharing characteristics with IE, IF, and IG isolates. Interestingly, the in silico analysis for IF and IG isolates revealed a different EcoRI profile compared to the description of Alexandre et al. ${ }^{20}$. The method applied for genome sequencing of these isolates ${ }^{21}$ may have selected virus genotypes. Genetic heterogeneity of wild-type isolates is well documented for baculoviruses ${ }^{20,31,32}$.

Although the pathogenicity is important to select an isolate, it does not always reflects its potential for biocontrol in the field, where the conditions are different and much more variable $^{33}$. Other phenotypic features like OB production could be higher in less virulent isolates, as demonstrated for SfMNPV ${ }^{34}$. In the case of ChinNPV-Buritis, natural epizootics resulted in the control of $30 \% \mathrm{C}$. includens population in a soybean field ${ }^{5}$.

The potential for in vitro production of this isolate was tested, because the difficulties of in vivo production of ChinNPV need to be overcome. Although this isolate was able to infect SF21, Sf9, and Tn-5B1-4 cell lines, the best OBs production was obtained in the last one. However, serial passages in Trichoplusia ni cells (Tn-5B1-4) were not successful and the infection appeared to be restricted to individual cells. According to Reid et al. ${ }^{6}$, one of the requirements for a cell line to be considered for in vitro production of a baculovirus is its capacity to produce a useful virus at a yield of at least $300 \mathrm{OBs} / \mathrm{cell}$. Therefore, improvements are necessary for further development of in vitro ChinNPV production.

Both AgMNPV and ChinNPV were able to infect cells originated from other insects $(S$. frugiperda and $T . n i$ ), although AgMNPV cannot cause a patent infection in $C$. includens larvae. Similarly, ChinNPV caused only covert infection in $A$. gemmatalis larvae. For a productive infection, cellular structures and molecular pathways must be compatible with the virus for all the major events in virus replication including attachment, entry, uncoating, replication, assembly, and exit. Insects have evolved methods to inhibit or block virus infections. These defense mechanisms include physical barriers along with local and systemic responses. The latter includes the production of antimicrobial peptides and highly specialized cells called hemocytes ${ }^{35}$. Resistance to AgMNPV was reported in laboratory selected populations of $A$. gemmatalis from Brazil and USA continuously exposed to the virus for 4 generations ${ }^{36}$.

The in vitro and in vivo co-infection has been successfully achieved using different genotypes of certain baculovirus species ${ }^{10,11,12}$. The biological features of mixed virus populations includes increased pathogenicity ${ }^{11}$ or increased pathogenicity and virulence ${ }^{12}$, although some works described reduced pathogenicity due to the presence of defective genotypes ${ }^{37}$.

Particularly in our co-infection study, a disproportionate amount of AgMNPV and ChinNPV was observed in the OBs used as inoculum. As a result, the amount of each virus varied considerably in the progeny. Maintenance of a certain genotype in the occluded virus 
population as the progeny virions are passed in subsequent host generations depends upon individual larval cells becoming co-infected with both viruses. The infection in an individual larva can be initiated with a disproportionate mixture, producing high variation in the percentage of virus genotypes ${ }^{10}$. The challenge presented for co-infection of AgMNPV and ChinNPV is to find a common and suitable host, either in vitro or in vivo.

The qPCR developed in this study proved to be a useful tool to detect and quantify these two viruses, AgMNPV and ChinNPV in several conditions: from purified OBs, infected larvae, infected cells, or from BVs in the cell culture supernatant. We also efficiently detected the viruses from larvae hemolymph (data not shown). The qPCR is a faster and more sensible method than the traditional techniques to quantify viral genotypes in BVs and OBs, although it is more expensive. In addition, AgMNPV is used for biological control in Brazil as biopesticides formulations, which present difficulties to traditional OBs quantification. We successfully detected AgMNPV from a formulated wettable powder with the qPCR technique (data not shown). The qPCR method is useful for a wide range of applications in field and laboratory. Barrera et al. ${ }^{29}$ developed a qPCR that detected granulovirus from samples of larva and soil, plus determined the virus concentration in the pesticide formulated as emulsifiable concentrate. According to the authors, this technique is reproducible, sensitive, and specific to allow viral persistence studies in the field, viral infection control in insect rearing, and quality control of a biopesticide based on baculovirus. In addition, qPCR is a powerful technique to detect viruses in asymptomatic insects. The persistence of viruses in natural populations, as the result of surviving a non-lethal virus challenge may play an important role in epizootics ${ }^{33}$ and might be better investigated with this technique.

\section{CONCLUSION}

ChinNPV-Buritis is a potential isolate for the development of biopesticide. In vivo and in vitro production studies with this isolate are being conducted for further formulation and field application. The methods presented here can be applied in future co-infection assays and open new possibilities of future research to investigate the effect of non-lethal doses and the implications on vertical transmission of ChinNPV and AgMNPV.

Funding: This research was funded by Fundação de apoio à pesquisa do DF (FAP-DF) (PPP/FAPDF/CNPq), grant number 193.000.661/2015.

Acknowledgments: Dr. James E. Maruniak (University of Florida, USA) for providing the Sf9 and IPLB-SF-21AE cell lines and Dr. Robert Granados for providing the BTI-Tn-5B1-4 cell line. To Embrapa Recursos Genéticos e Biotecnologia Insects Platform for insects rearing. To Dr. Rogerio B. Lopes to provide the ChinNPV isolate from Buritis-MG, Brazil. To Fabio Eduardo Paro and Ivanilda Luzia Soldorio for support with the bioassays.

Conflicts of Interest: The authors declare no conflict of interest.

\section{REFERENCES}

1- Sosa-Gómez DR. Microbial control of soybean pest insects and mites. In: Lacey, L.A., editor. Microbial control of insect and mite pests: from theory to practice. Amsterdam, Netherlands: Elsevier; 2017. 199-208 p.

2- Conte O, Oliveira FT, Harger N, Correa-Ferreira BS. Resultados do manejo integrado de pragas da soja na safra 2013/14 no Paraná. Londrina, PR, Brazil: Embrapa Soja; 2014. 
3- Lapointe R, Thumbi D, Lucarotti CJ. Recent Advances in Our Knowledge of Baculovirus Molecular Biology and Its Relevance for the Registration of Baculovirus-Based Products for Insect Pest Population Control. In: Soloneski, S., editor. Integrated Pest Management and Pest Control - Current and Future Tactics, Rijeka, Croatia: InTech; 2012. 481-522 p.

4- Moscardi F. Assessment of the application of baculoviruses for control of Lepidoptera. Annu Rev Entomol. 1999; 44:257-89.

5- Souza ML, Sihler W, Sanches MM, Schmidt FGV, Benito NP, Lopes-Silva M, Faria M, Lopes RB. Ocorrência de baculovírus em larvas de Chrysodeixis includens em cultivo de soja na região do cerrado - Boletim de Pesquisa e Desenvolvimento 313. Brasilia, DF, Brazil: Embrapa; 2015.

6- Reid S, Chan L, Van Oers M. Production of Entomopathogenic Viruses. In: Morales-Ramos, J.; Rojas, G.; Shapiro-llan, D. editors. Mass Production of Beneficial Organisms: Invertebrates and Entomopathogens. London, UK: Elsevier Inc.; 2014. 437-482 p.

7- Castro MEB, Ribeiro ZMA, Souza ML. Infectivity of Anticarsia gemmatalis nucleopolyhedrovirus to different insect cell lines: Morphology viral production and protein synthesis. Biol Control. 2006; 36:299-304.

8- Almeida AF, Macedo GR, Chan LCL, Pedrini MRS. Kinetic analysis of in vitro production of wild-type Spodoptera frugiperda Nucleopolyhedrovirus. Braz Arch Biol Technol. 2010; 53:28591.

9- Huynh HT, Tran TTB, Chan LCL, Nielsen LK, Reid S. Decline in Helicoverpa armigera nucleopolyhedrovirus occlusion body yields with increasing infection cell density in vitro is strongly correlated with viral DNA levels. Arch Virol. 2015; 160:2169-80.

10- Hamblin M, Van Beek NAM, Hughes PR, Wood HA. Co-Occlusion and persistence of a baculovirus mutant lacking the polyhedrin gene. Appl Environ Microbiol. 1990; 56:3057-62.

11- López-Ferber M, Simon O, Williams T, Caballero P. Defective or effective? Mutualistic interactions between virus genotypes. Proc R Soc Lond B. 2003; 270:2249-55.

12- Arrizubieta M, Simón O, Williams T, Caballero P. A novel binary mixture of Helicoverpa armigera single nucleopolyhedrovirus genotypic variants has improved insecticidal characteristics for control of cotton bollworms. Appl Environ Microbiol. 2015; 81:3984 -93.

13- Wood HA, Hughes PR, Shelton A. Field Studies of the co-occlusion strategy with a genetically altered isolate of the Autographa californica nuclear polyhedrosis virus. Environ Entomol. 1994; 23:211-9.

14- Hoffmann-Campo CB, Oliveira EB, Moscardi F. Criação massal da lagarta da soja (Anticarsia gemmatalis). Londrina, PR, Brazil: Embrapa Soja; 1985.

15- Greene GL, Leppla NC, Dickerson WA. Velvetbean catterpillar: a rearing procedure and artificial medium. J Econ Entomol. 1976; 69:487-8.

16- Johnson DW, Maruniak JE. Physical map of Anticarsia gemmatalis nuclear polyhedrosis virus (AgMNPV-2D) DNA. J Gen Virol. 1989; 70:1877-83.

17- Maruniak JE. Baculovirus structural proteins and protein synthesis. In: Granados, R.R.; Federici, B.A., editors. The biology of baculovirus. Volume I. Florida, USA: CRC Press; 1986. 129-146 p.

18- O'Reilly DR, Miller LK, Luckow VA. Baculovirus Expression Vectors: A Laboratory Manual. New York, NY, USA: Cold Spring Harbor Laboratory; 1992. 
19- Sambrook J, Russel DW. Molecular Cloning: a laboratory manual 3rd ed. New York, NY, USA: Cold Spring Harbor; 2001.

20- Alexandre TM, Ribeiro ZMA, Craveiro SR, Cunha F, Fonseca ICB, Moscardi F, Castro MEB. Evaluation of seven viral isolates as potential biocontrol agents against Pseudoplusia includens (Lepidoptera: Noctuidae) caterpillars. J Invertebr Pathol. 2010; 105:98-104.

21- Craveiro SR, Santos LAVM, Togawa RC, Inglis PW, Grynberg P, Ribeiro ZMA, Ribeiro BM, Castro MEB. Complete genome sequences of six Chrysodeixis includens nucleopolyhedrovirus isolates from Brazil and Guatemala. Genome Announc. 2016;4: e01192-16.

22- Morales L, Moscardi F. Comparação entre duas metodologias de bioensaios para vírus entomopatogênicos. An Soc Entomol Brasil. 1993; 22:535-40.

23- Abbott WS. A method of computing the effectiveness of an insecticide. J Econ Entomol. 1925; 18:265-6.

24- Finney DJ Probit Analysis. New York, NY, USA: Cambridge Univ Press; 1971.

25- Granados RR, Guoxun L, Derksen ACG, Mckenna KA. A new insect cell line from Trichoplusia ni (BTI-Tn-5B1-4) susceptible to Trichoplusia ni single nuclear polyhedrosis virus. J Invertebr Pathol. 1994; 64:260-6.

26- Vaughn JL, Goodwin RH, Tompkins GJ, Mccawley P. The establishment of two cell lines from the insect Spodoptera frugiperda (Lepidoptera: Noctuidae). In Vitro. 1977; 13:213-7.

27- Granados RR, Li G, Blissard GW. Insect Cell Culture and Biotechnology. Virol Sin. 2007; 22:839.

28- Oliveira JVC, Wolff JLC, Garcia-Maruniak A, Ribeiro BM, Castro MEB, Souza ML, Moscardi F, Maruniak JE, Zanotto PMA. Genome of the most widely used viral biopesticide: Anticarsia gemmatalis multiple nucleopolyhedrovirus. J Gen Virol. 2006; 87:3233-50.

29- Barrera G, Murcia J, Cerón J, Cuartas P, Guzmán C, Villamizar L. PCR en tiempo real: una metodología útil para la detección y cuantificación de granulovirus. Rev Colomb Biotecnol. 2016; 18:24-31.

30- Botelho SRA, Martins TP, Duarte MF, Barbosa AV, Lau D, Fernandes FR, Sanches MM. Development of methodologies for virus detection in soybean and wheat seeds. MethodsX. 2016; 3:62-8.

31- McIntosh AH, Rice WC, Ignoffo CM. Genotypic variants in wild-type populations of baculoviruses. In: Maramorosch, K., editor. Biotechnology in Invertebrate Pathology and Cell Culture. San Diego, CA, USA: Academic Press; 1987. 305-325 p.

32- Simón O, Williams T, López-Ferber M, Caballero P. Functional importance of deletion mutant genotypes in an insect nucleopolyhedrovirus population. Appl Environ Microbiol. 2005; 71:4254-62.

33- Cory JS, Evans HF. Viruses. In: Lacey, L.A.; Kaya, H.K., editors. Field Manual of Techniques in Invertebrate Pathology: Application and Evaluation of Pathogens for Control of Insects and Other Invertebrate Pests 2nd ed. Dordrecht, ZH, Netherlands: Springer; 2007. 149-174 p.

34- Barrera G, Williams T, Villamizar L, Caballero P, Simón O. Deletion phenotypes reduce occlusion body potency but increase occlusion body production in a Colombian Spodoptera frugiperda nucleopolyhedrovirus population. PLoS ONE. 2013;8: e77271.

35- Rohrmann GF. Baculovirus Molecular Biology. 3rd ed. Bethesda, USA: National Center for Biotechnology Information; 2013. 
36- Abot AR, Moscardi F, Fuxa JR, Sosa-Gómez DR, Richter AR. Development of resistance by Anticarsia gemmatalis from Brazil and the United States to a nuclear polyhedrosis virus under laboratory selection pressure. Biol Control. 1996; 9:126-30.

37- Muñoz D, Castillejo JI, Caballero P. Naturally occurring deletion mutants are parasitic genotypes in a wildtype nucleopolyhedrovirus population of Spodoptera exigua. Appl Environ Microbiol. 1998; 64:4372-7.

CC) 2018 by the authors. Submitted for possible open access publication
under the terms and conditions of the Creative Commons Attribution (CC
BY NC) license (https://creativecommons.org/licenses/by-nc/4.0/). 